研 究 報 文

\title{
製紙工場のクローズド化が機械パルプファイン物性に及ぼす影響
}

\author{
日本製紙株式会社 技術研究所 上條 康幸, 宮西 孝則
}

\section{The Effect of Mill Closure on Properties of Mechanical Fines}

Yasuyuki Kamijo and Takanori Miyanishi

Pulp \& Paper Research Laboratory. Nippon Paper Industries Co., Ltd.

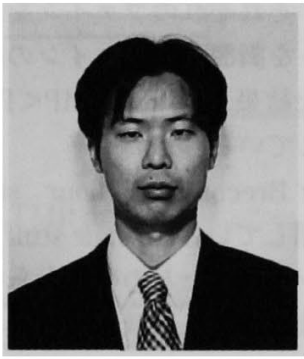

上條康幸

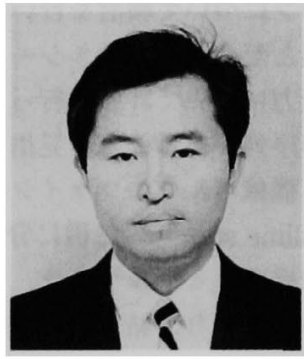

宮西孝則

The effect of dissoloved and colloidal substances (DCS) in TMP (thermomechanical pulp) white water on the strength properties of handsheets and the flocculation capability of fines with retention aids were investigated.

For this experiment, two types of fines were prepared. One is water-washed TMP fines and the other is white-water TMP fines which were fractionated with TMP white water. Breaking length and surface strength of the handsheets containing water-washed TMP fines were higher than that of the handsheets containing white water TMP fines. It is suggested that DCS adsorbed on white water TMP. fines had a detrimental influence on fiber bonding.

The extent of flocculation of fines in the white water of a newsprint machine was measured by Photometric Dispersion Analyzer (PDA). The results of flocculation experiments showed that fines extracted with acetone were more easily flocculated with cationic retention aids than fines in white water. The molecular weight of retention aids affected the flocculation of the fines in white water.

It is concluded that DCS has negative effects on sheet strength and on the flocculation of fines with retention aids.

Keywords : thermomechanical pulp, fines, dissolved and colloidal substances (DCS), sheet strength, flocculation

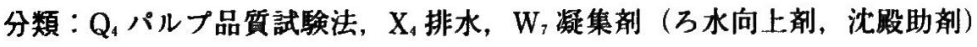

1. 緒

言

紙の品質に影籍を与えるものとして,ファインの存 在が挙げられる。

ファインは $76 \mu \mathrm{m}$ 以下の画分と定義され, パルプ 䄉維が微細化したファイバーファインと填料ファイン
に大別される”。填料ファインはデボンディングを引 き起こすため, 秖の強度を低下させるが, ファイバー ファインは一般的に比表面積が長䄉維の約 5 8 倍と 大きく"', 織維間水素結合の形成などに寄与すること から, 表面強度や引張り, 引裂き强度の様な物理的な 性質, 不透明度や白色度といった光学的性質に影響を 
与える。

ファイバーファインの研究としては, パルプ化工程 において多量のファインが生成する砕木パルプ (SGW), 加圧式砕木パルプ (PGW), サーモメカニ カルパルプ (TMP) のような機械パルプを中心に検 討が行われている。Corsonは TMP ファインが引張 り強度に与える影锌について検討を行い, 紙中のファ イン含有量が增加するにつれて湿紙強度, 密度, 引張 り強度が向上する結果を得ている゙”。た Lindholm は, SGW, PGW，TMPの 3 種類のファイバーファ インについて検討を行い, それぞれのファインを長縺 維と配合して手抄きシートを調製し，ファインの結合 能力について評価を行った結果, SGW $<\mathrm{TMP}<\mathrm{PGW}$ の序列があることを見出している゙。

機械パルプのファインをBrecht らは “flour stuff”, "slime stuff" の二種に分類している。"flour stuff” は 耭維壁, ミドルラメラ, レイセルなどの砕片から構成 されており, 結合能力が低く此散乱保数に寄与する特 徽を持っているのに対し, "slime stuff”は䄉維表面 から脱落したリボン状の物質, フィブリルや薄いラメ ラなどから構成され, 結合能力に寄与するとされてい る5゙。Luukkoらはファインの形態を詳細に観察し, 前述の "flour stuff", "slime stuff"をそれぞれ“フレ ーク状ファイン”, “フィブリル状ファイン”と呼んで 分類している

また, ファイバーファインは生成過程により一次, 二次, 三次の三種に区分される。一次ファインは木材 パルプ中に元々含まれていたファインで,これには采 細胞, 放射組織細胞及び広葉樹材の導管が含まれる。 また, 二次ファインはパルプの吒解の際発生するファ インで，細胞壁層の膜状物犋を含め，一次ファインと 同様の形状をしている。更に三次ファインは抄紙機の ワイヤー上に歩留らなかった原料が白水系を循環して いる間に生成するファインである。この分類方法によ ると一次, 二次ファインは, ファインの生成個所によ り分類されることになり, 機械パルプと化学パルブに もそれぞれ一次, 二次ファインがある。しかし機械パ ルプの一次ファインと化学パルフのの一次ファインを比 較すると, 前者は中間層由来のリクニンを多く含んで いるため,その結合能力などは異なっている。

抄紙工程においてもファインは重要な役割を担って いる。抄造前には紙料に硫酸バンド, 紙力剂, 歩留向 上剤など様々なウェットエンド薬品が添加されるが, 比表面栍が大きなファインは長樴維よりも薬品吸着量 が高く, 硫酸バンドの場合では長織維の約 2 3 倍, エマルション型ロシシサイスでは長倳維の約 16 20
倍吸着すると報告されている ${ }^{21}$ 。従って, 添加薬品の 効果は薬品が吸着したファインの歩留りに依存するこ とになる。

ウェットエンド化学は抄紙系内の $\mathrm{pH}$, ゼー夕電位, カチオン要求量などを薬品添加により制御し，抄紙機 の操業状態の安定化, 生産性の向上を図ることを目的 としているが, ファインのワンパスリテンション向上 が最大の焦点となっている。ファインのワンパスリテ ンションを向上させれば, 湿紙強度の向上による断紙 の減少, 白水中を循環している物質が隇少することに よる系内の清浄化, 更には紙質面に関しても, インレ ット濃度が減少することから地合の良化が期待でき る”。

ワンパスリテンションを低下させる物質としては, カチオン性の歩留向上剤が紙料に定着する前に相互作 用し，その添加効果を低下させる溶存コロイド成分が 知られている。リグニン誘導体, 木材抽出成分, コー トブロークなど溶存コロイド成分の起源は様々であ $\eta^{8)}$, これらの処理方法も詳細な検討が行われている9”。

ファインのワンパスリテンションが低い場合には, 多量のファインと共に溶存コロイド成分が白水中を循 罢することになるが，ウェットエンド薬品との相互作 用のみならず溶存コロイド成分のファインへの影響と いった観点からの評価については，ほとんど知見が得 られていない。そこで本研究では TMP のファインを 取り上げ, 溶存コロイド成分の影幚についてモデル寒 験を行った。また白水中のファインに対する歩留向上 剤の添加効果についても検討を行った。

\section{2. 実験}

\section{1 試料調 製}

\subsubsection{TMP ファインの調製101}

原料には晒 TMP を用いた。

唒 TMP 調製工程を図 1 に示す。図 1 のように白水 は原料の希釈水としてリファイナーやチェストに添加 されている。モデル実験ではリファイナーチェストの 紙料を使用した。

TMP ファインの調製については, Scheme 1 に従 って行った。篩い分けをTAPPI T 261 pm-79に従っ て行うと,ファイン表面上に吸着している成分の脱着 などが考えられるため，原料の滤液で希釈して箱い分 けを実施した。TMPをNo.2 滤紙 (ADVANTEC) で 予め滤過を行い，原料をこの滤液で希釈した後にワイ ヤーメッシュ（200メッシュ，孔径 $76 \mu \mathrm{m} ）$ を取りつ けたタイナミックドレネージジャー(DDJ)に入れ, 750 $\mathrm{rpm}$ で挜找しながら篩い分けを行った。得られたフ 


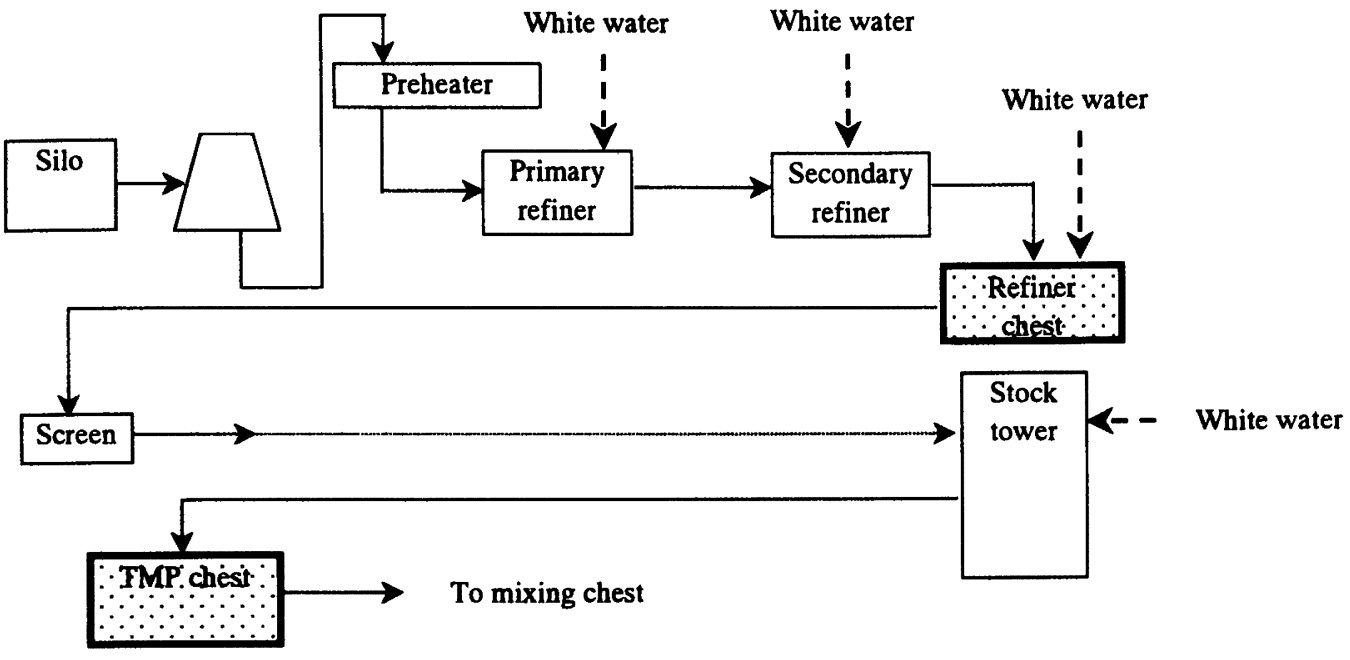

Fig. 1 The flowsheet for TMP process
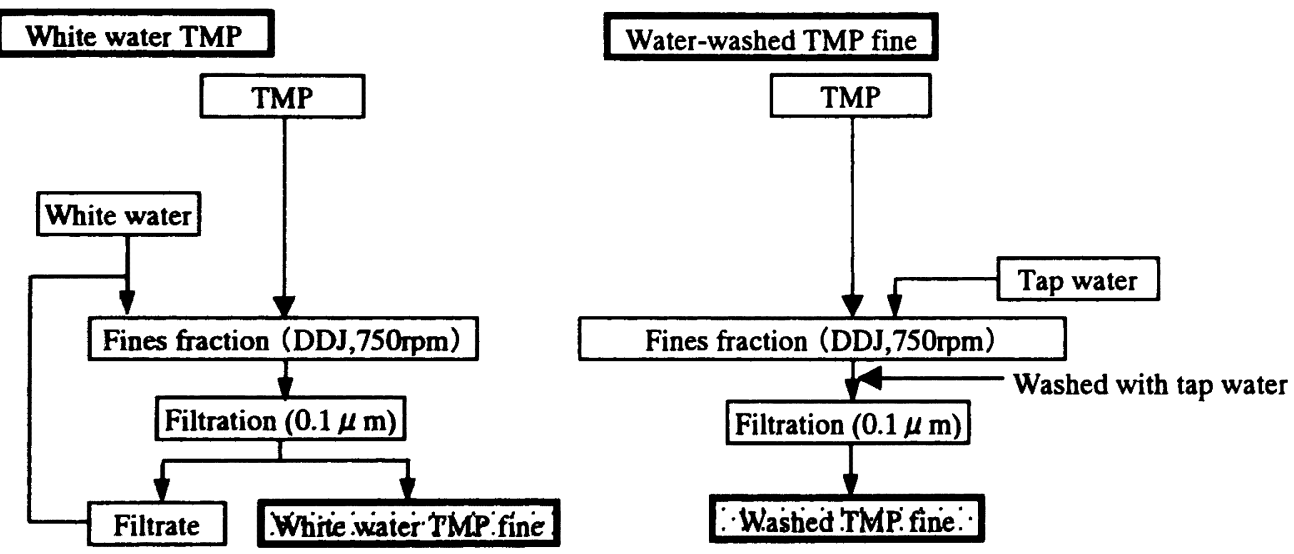

Scheme 1

アインはメンフランフィルター (ADVANTEC, 孔 径 $0.1 \mu \mathrm{m})$ により吸引滤過を行った。篩い分けの操 作中に生じた滤液は，原料の希积液として回収した。 この方法で得られたファインを以下白水 TMP ファイ ンとする。

また, 白水 TMP ファインとの比較のため, 清水で 節い分けを行ったファインの調製も行った。この場合 のファインは，水道水で希釈しながら節い分けを行い， メンフランフィルター (ADVANTEC, 孔径 $0.1 \mu \mathrm{m}$ ) による吸引滤過の際にも水道水で洗浄を行った。ここ で得られたファインを以下洗净 TMP ファインとする。

\section{1 .2 白水ファイン，抽出ファインの調製101}

新閏マシンのワイヤー下白水を採取して穊い分けを 行い，歩留向上郕添加による凝集性の測定に使用した。 節い分けの方法は前述の白水 TMP ファイン調製の方
法と同様である。このファインを白水ファインとする。 更に，表面の吸着成分を除去したファインの調製に ついては, Scheme 2 に示したように，得られた白水 ファインをアセトン：水 $=80: 20(\mathrm{~V} / \mathrm{V})$ の混合溶媒 に入れ、アジテーターを用いて 20 時間室温で畓找を 行った。その後 $2,800 \mathrm{rpm}$ で遠心分離を行い, 上澄 み液をデカンテーションにより除去した。次に蒸留水 を入れて $40^{\circ} \mathrm{C} て ゙ 2$ 時間港找を行い，アセトンを完全 に除去するために室温で更に 20 時間放置後，メンフ ランフィルター（ADVANTEC，孔径 $0.1 \mu \mathrm{m}$ ）を用 いて吸引滤過を行った。この方法で得られたファイン を以下抽出ファインと表記する。なお，本実験で使用 したファインの灰分は $24 \%$ であった。 


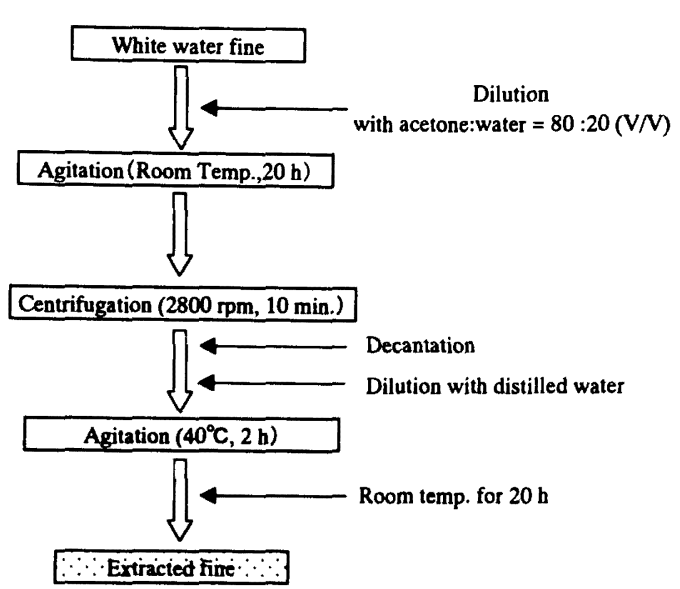

Scheme 2

\section{2 実験操作}

\subsection{1 溶存コロイド成分が TMPファインに} 与える影霎

白水 TMP ファイン, 洗浄 TMP ファインをそれぞ れ TMP 長瀻維と混ぜて, JIS P 8209 に従い手抄きシ ートを調製した。調製した手抄きシートについては, 引張り強度を測定し混合したファインの影響について 評価を行った。また，JIS P 8209 に基づいてIGT 印 刷適性試験機により加速印刷試験を行い、シートのム ケ発生速度の測定を行った。

\subsection{2 ファインの凝集性}

ファインの凝集性の評価に関しては, Phtometric Dispersion Analyzer (PDA-2000, Rank Brothers 社)
を使用した。図2に示すようにこの装置は流動して いる粒子の凝集による濁度 V (dc 信号) と透過光強 度の摇らぎ (ac 信号) を測定する。ac 信号の平均自 乗根 $\left(\mathrm{V}_{\mathrm{rms}}\right.$ 值) は濁度の標準偏差に対応しており, 形 成された凝集体の凝集度とサイスに関連している。本 研究では RMS 值として, チューブ壁の侠雑物の影䍌 をほとんど受けない変動係数 $\left(\mathrm{V}_{\mathrm{rms}} / \mathrm{V}\right)$ を測定した。 検出される信号は凝集体の光散乱性と物質自体に依存 するため, 凝集体のサイズをこの機器により決定する ことは困難であるが, 凝集度の変化を測定する点に関 しては有用な分析器機であるといえる。Krogerus は ファイバーファインとクレーの㠜集性について PDA を用いた評価を行っている(1).12)。

凝集性の評価は，図了に示す装置により行った。蒸 留水に白水ファイン, 或いは抽出ファインを分散させ た貯藏液を調製し，この貯蔵液 $15 \mathrm{~mL}$ 蒸留水 800 $\mathrm{mL} に$ 加えて, 希硫酸によりファインサスペンション の $\mathrm{pH}$ を 5.0 に調整した。マグネチックスターラーに

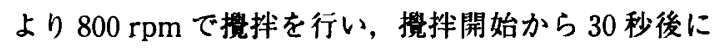
歩留向上凰を $300 \mathrm{ppm}$ (対ファイン絶乾重量) 添加し て RMS 値を測定した。なお，実験に使用したポリマ 一の物性値を表 1 に示す。

得られた RMS 值は，相対 RMS 值として表記した。 相対 RMS 值は, (相对 RMS 值) $=\left(\mathrm{RMS}_{1}\right) /\left(\mathrm{RMS}_{0}\right)$ で算出した。

ここで, $\mathrm{RMS}_{\mathrm{t}}=$ 時間 $\mathrm{t}$ に観測された $\mathrm{RMS}$ 値, $\mathrm{RMS}_{0}$ =測定直後に観測された RMS 值であり，相対 RMS 值が大きいほど大きな凝集体が形成されていることを
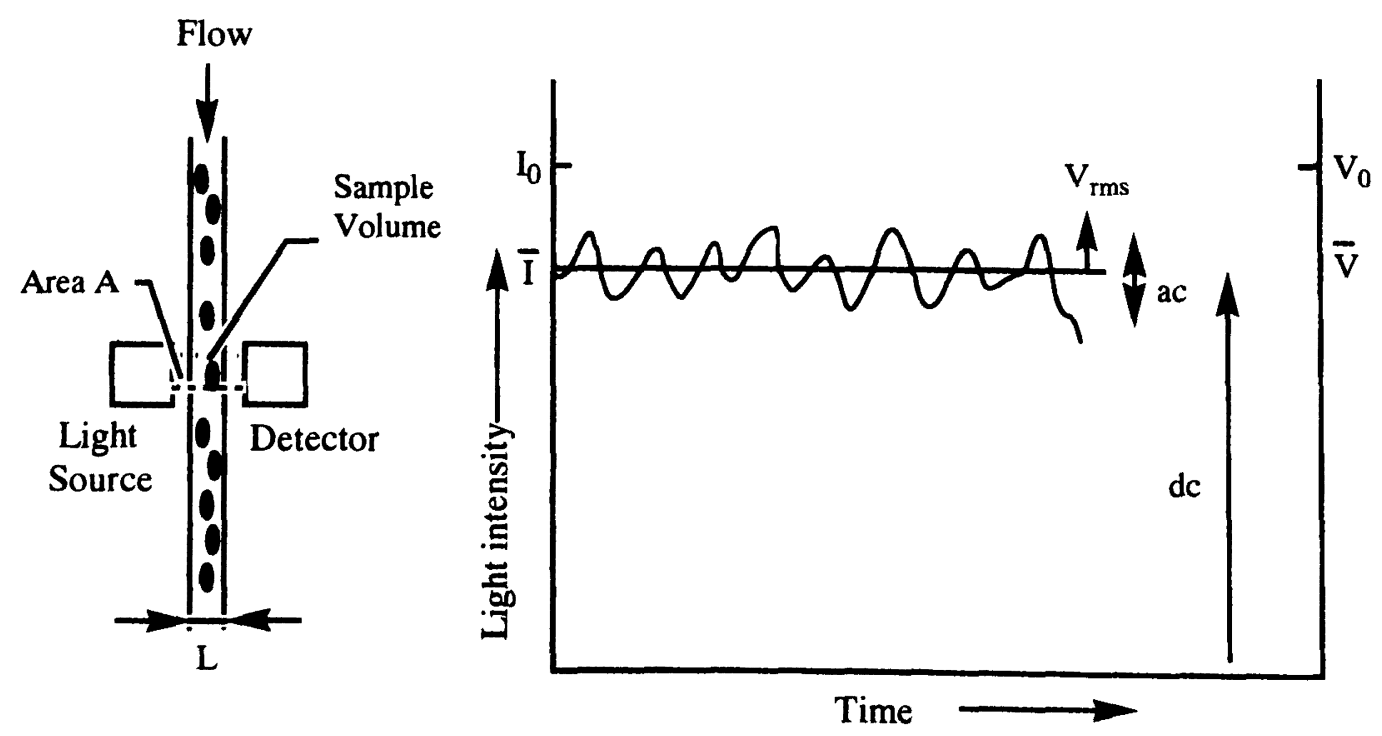

Fig.2 Measuring principle of the photometric dispersion analyzer (PDA) 
Table 1 Properties of the flocculants used in experiments

\begin{tabular}{lccc}
\hline & Type & Molecular weight & Charge density (meq/g) \\
\hline Polymer A & Cationic PAM & $8 \times 10^{6}$ & 1.33 \\
Polymer B & Cationic PAM & $8 \sim 9 \times 10^{6}$ & 2.77 \\
Polymer C & Cationic PAM & $15 \sim 20 \times 10^{6}$ & 1.12 \\
\hline
\end{tabular}

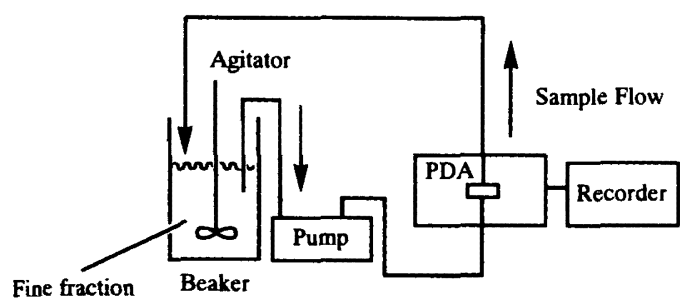

Fig. 3 A schematic diagram of the instrument of flocculation experiment

示す。

\section{3. 結果と考察}

\section{1 溶存コロイド成分が TMPファインに与える 影霎}

\subsection{1 引張強度試験}

引張試験結果を図 4 に示す。長樴維のみの裂断長は $1.93 \mathrm{~km}$ であり,すべての原料についてファイン配合 量が高くなるにつれ裂断長が增加した。シート中のフ アイン存在量が增加するにつれて臷維間結合が強化さ れ，その結果シートの裂断長が增加したものと考えら れる。白水 TMP ファイン, 洗埩 TMP ファインの比 較を行ったところ，ファイン配合量か $20 \% ， 30 \%$ の 場合，洗浄 TMP ファインが配合されたシートの裂断 長は，白水 TMP ファインを配合した場合と比較して 高い結果が得られた。Brandal らは, Scotch pine と Norway spruce から製造された SGW についてアセト ン,アルベン，エーテルから抽出を行い，紙質に与え る影響を調査しているが，抽出により裂断長，比破裂 強度, 比引裂き強さが向上する結果を得ており，樹脂 酸，脂肪酸などのモデル化合物を紙料に添加して評価 を行ったところ，特に脂肪酸なとの直鎖型化合物を添 加した場合には強度低下が大きいことを報告してい

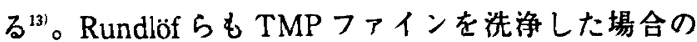
強度向上を確認しており，更にファイン表面を ESCA により測定した結果，洗浄により C一C 結合の減少を 示したことから，洗浄による抽出成分の除去により強 度が向上したと報告している ${ }^{10.140}$ 。今回の実験結果も

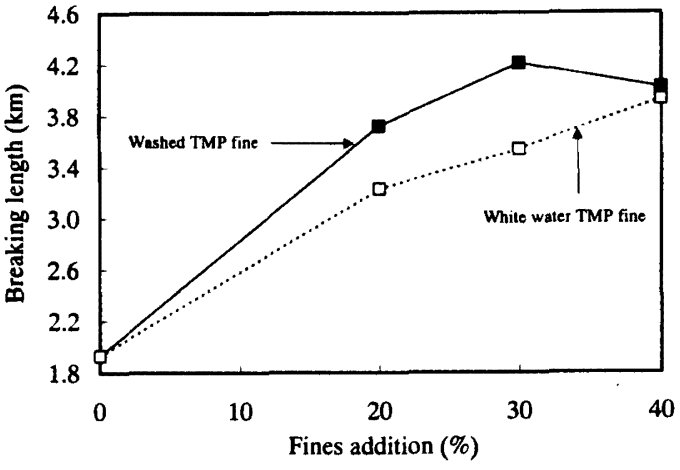

Fig. 4 Effect of fines addition on breaking length

前述の報告と同様に，洗浄 TMP ファインが調製され た際には，洗浄により表面に吸着していた抽出成分が 脱着し, 抽出成分により被倠されていた親水性表面が 暴露されたと考えられる。その結果, 洗净 TMP ファ インが長織維間にファインが介在した場合には綫維間 水素結合が形成され，白水 TMP ファインを配合した 場合と比較して裂断長が增加したものと推定される。

\subsubsection{IGT 印刷試験}

ファインが表面強度に及はす影響に関して IGT 印 刷試験による評価を行った。この測定では紙剥けの発 生速度 Viを算出して評価の指標とした。 $V_{i}$ は次式で 算出される。

$$
\mathrm{Vi}=\left\{\left(\mathrm{V}_{0}{ }^{2} / \mathrm{S}_{0}\right) \times \mathrm{S}_{1}\right\}^{1 / 2}
$$

ここで， $\mathrm{V}_{0}$ ：最終速度 $5 \mathrm{~m} / \mathrm{sec} ., \mathrm{S}_{0}$ ：全印刷長さ 20 $\mathrm{cm}, \mathrm{S}_{1}$ : 剥け発生距離である。式中の $\left(\mathrm{V}_{0}{ }^{2} / \mathrm{S}_{0}\right)$ は定 数であることから $\mathrm{V}_{\mathrm{i}}$ は剥け発生距離に依存し、この 值が大きいほどシートの表面強度が高いことを示して いる。

図 5 に示したように，表面強度は前述の引張試験結 果と同し傾向を示しており，ファイン配合率が增加す るに従って紙剥け発生速度が上昇し, 紙面強度が增加 したがフファイン添加量 30\%でほほ飽和に達してい た。また，白水 TMP ファインを配合したシートは， 洗浄 TMP ファインを配合したシートと比較して紙剥 け発生速度が低く、シート表面強度が低下する傾向が 認められた。 


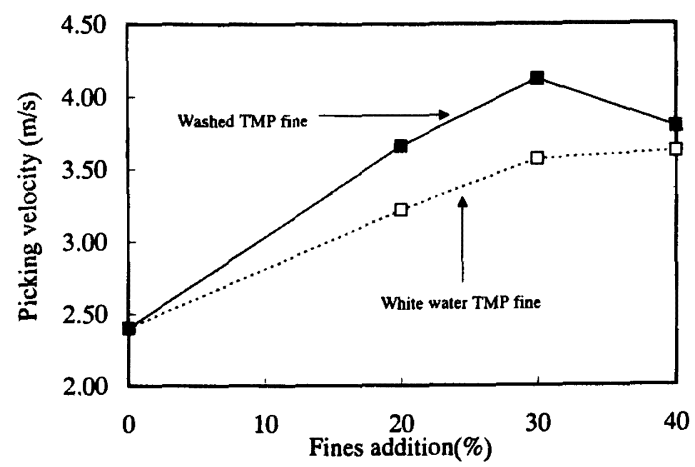

Fig. 5 Effect of fines addition on surface strength Printing conditions; ink : leoecoo type $\mathrm{M}$ black (Toyo ink, tack value :6.7), printing pressure $: 30 \mathrm{~kg} / \mathrm{cm}$, printing velocity $: 5$ $\mathrm{m} / \mathrm{s}$ (increasing velocity).

裂段長，表面強度共にファイン配合率約 30\% でほ ほ飽和に達していたが，以前筆者らは，新聞原料を長 䄉維分とファイン分とに分画後, ファイン添加率を変 化させた手抄きシートを作成し，ファインが表面強度 に与える影響に関して IGT 印刷試験により評価を行 っているが、この場合にもファイン添加率 20〜30\% でシート表面強度が飽和する知見を得ている イバーファインは長織維の結合点を補強する役割を果 たすが，その結合点は無限にあるわけではなく，ファ イバーファイン添加率が $20 \%$ 30\% で飽和している ものと推定される。

\section{2 白水循環したファインに対する薬品の 添加効果}

前項では，洗浄によりファインの結合能力が回復し て裂断長及び表面强度が向上することを示した。現在 抄紙工程で使用されている歩留向上霅, 紙力棛, 凝結 片等のウェットエンド菓品の多くはカチオン性を示す ものが大半であり, ファイン表面上のアニオン性部位 に吸着され，添加効果を発現する機構が支持されてい る ${ }^{16 !}$ 。ファインが白水中を循環する際に, 抽出物が表 面上に吸着してファイン表面上のアニオン性部位を被 覆するものと仮定すれば，ウェットエンド薬品の添加 効果が低下するものと考えられる。そこで, 白水中の ファインにカチオン性の歩留向上率を添加した場合の 凝集性について，PDAを用いて評価を行った。また， 白水中のファインをアセトンー水で抽出した抽出ファ インの凝集性との比較を行った。

図6にはファインにポリマーAを添加した場合の 凝集挙動を示した。相対 RMS 值は測定開始から 150

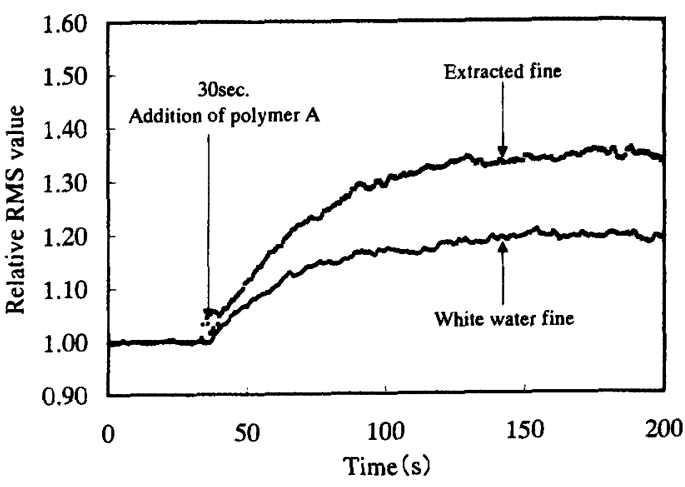

Fig.6 Flocculation of fines with polymer A

秒後にはほほ一定值を示し, 白水ファインの相対 RMS 值が 1.20 , 抽出ファインでは 1.34 となり, アセトン 一水で抽出することによりファインの凝集性が向上す ることが明らかとなった。アセトンー水混合溶媒によ る抽出物量は $23.7 \mathrm{mg} / \mathrm{g}$ （ファイン絶乾重量）であり， 水洗浄と同ように，抽出によりファイン表面に吸着さ れていた溶存コロイド成分が除去され，添加薬品の吸 着性が向上したことに起因していると考えられる。ポ リマーB, ポリマーCの場合でも, 白水ファインと 此較して抽出ファインの相対 RMS 值が高く, 歩留向 上郕の添加による凝集効果が向上する傾向が認められ た（図には示さない)。

この解釈が罗当であるかを確認するために，試料サ スペンションのカチオン要求量測定を行った。仮にサ ンブルのカチオン要求量が異なれば, 存在する溶存コ ロイド成分が添加された歩留向上㓮と相互作用し，そ の結果凝集性が低下した可能性が考えられる。そこで PDA 測定をする前に，調製したファインサスペンシ ヨンのカチオン要求量を流動電流検出器 (Charge Analyzer II，Rank brothers 社）を用いて測定した。 その結果, 白水ファインサスペンションのカチオン要 求量は $10.0 \mu \mathrm{eq} / \mathrm{L}$, 抽出ファインサスペンションの カチオン要求量が $11.7 \mu \mathrm{eq} / \mathrm{L}$ となり，カチオン要求 量についてははとんど差が認められない結果が得られ た。従って凝集性が低下したのは，サスペンション中 の溶存コロイド成分が影辢を与えたのではなく、ファ イン表面上に吸着している溶存コロイド成分が歩留向 上剤とファインとの相互作用を阻害したものと考えら れる。

図7は 3 つの凝集郕添加による白水ファインの凝集 性を比較したものである。測定開始から 150 秒後のポ リマーAの相対 RMS 值は 1.20 ,ポリマーBは 1.18 , ポリマーCは 1.38 であり，分子量が同程度で電荷密 


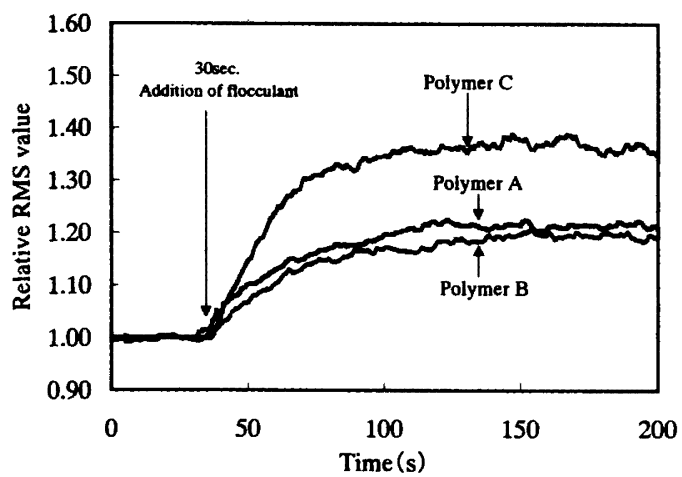

Fig. 7 Flocculation of white water fines with various flocculants

度の異なるポリマーA とポリマーBにはほとんど差 が認められなかった。また，ポリマーAと同程度の 電荷密度を持ち分子量が極めて高いポリマーCとの 比較では, ポリマーCの疑集力が高いことが明らか となった。従って白水中を循㻴したファインの凝集に は，歩留向上剤の電荷よりも分子量が優位に铺いてい ると考えられる。

\section{4. 結言}

溶存コロイド成分がTMP ファインに与える影䈉に ついてモデル実験を行った。TMPファインを一度穊 い分けにより分噰した後に，長織維に再度配合して手 抄きシートを作成し，引張强度及びIGT 印刷試験を 行った。その結果, 水で希釈, 洗浄しながら䈟い分け を行った洗浄 TMP ファインを配合したシートは，白 水稀釈により篩い分けを行った白水 TMP ファインを 配合したシートと比較して裂断長, IGT 印刷表面強 度が共に向上する結果が得られた。水による希积，洗 净の際に, TMP ファイン表面に吸着していた溶存コ ロイド成分が脱着して，械維間結合が回復したことに 起因すると推定される。

更に新開マシンの白水中に含まれるファインについ て, 歩留向上撤を添加した場合の凝集性の評価を光度 分散分析器 (PDA) を用いて行った。白水で希釈し ながら篲い分けを行った白水ファインと, 白水ファイ ンをアセトンー水混合溶媒から抽出した抽出ファイン の凝集性を比較したところ，抽出ファインの㠜集性が 向上する結果が得られた。この結果は, 白水中の溶存 コロイド成分がファイン表面に吸着し，ファインと歩
留向上剂の相互作用を阻害していることを示している。 また, 歩留向上剤の凝集性は電荷密度ではなく分子量 が大きく影籍を与えていることが明らかとなった。

本研究では，溶存コロイド成分が従来知られている ように抄紙工程で添加されるウェットエンド薬品と直 接相互作用してその効果を低下させるのみならず，間 接的にも添加効果を低下させることを示した。抄紙工 程での白水はパルプ化工程での希釈, 洗浄水として用 いられることから，ワンパスリテンションの向上と溶 存コロイド成分の処理はより重要な課題であるといえ る。

\section{参考文献}

1) Hagemeyer R. W., Manson D. W., Kocurek M. J. : Pulp and Paper Manufacture Vol. 6 Stock Preparation. Harpell's Press Co., 1983, 116

2) Scott W. E. : Tappi J.69 (11) 30 (1986)

3) Corson S. R. : Pulp and Paper Can.81 (5) T 108 (1980)

4) Lindholm C.-A. : Paperi ja Puu 62 (12) 803(1980)

5) Brecht W., Klemm K. : Pulp Paper Mag. Can. 54 (1) 72 (1953)

6) Luukko K., Paulapuro H. : Tappi J. 82 (2) 95 (1999)

7) Marton J., Marton T.: Principles of Wet End Chemistry, TAPPI PRESS, 1996, 1-3

8) Linhart F., Anhorn W. J., Degen H. J., Lorz R. : Tappi J. 70 (10) 79 (1987)

9）例えば Baak T., Gill G. J. : Paperi ja Puu 53 (8) 449 （1971）など

10) Rundlöf M., Höglund H.. Htun M.. Wagberg L. : J. Pulp and Paper Sci. 26 (9) 308 (2000)

11) Krogerus B. : TAPPI Papermakers Conf. Proc.. TAPPI PRESS, 1994, p 445-452

12) Krogerus B. : Nord. Pulp Pap. Res. J. 8 (1) 135 (1993)

13) Brandal J., Lindheim A. : Pulp and Paper Can. 67 (10) T 431 (1966)

14) Rundlöf M., Höglund H.. Htun M., Wảgberg L. : J. Pulp and Paper Sci. 26 (9) $301 \quad$ (2000)

15) Miyanishi T., Miyagi M. : Tappi J. 75(5) 76(1992)

16) Lindstrom T. Ekulund D. : Paper Chemistry: An Introduction. DT Paper Science Publications. 1991. 145-191

(受理：'02.12.20) 
ル）が達成されたかについて実際の運転データを用いながら紹介する。

BTF 全自動ダイューションシステムを導入すると, グレードチェンジ後の立ち上がりが極めて早 くなるが,これについてもドライエンドスキャナーのデータを使って，時間経過とともにどの様にプロ ファイルが収束していくかをご紹介したい。これにより，スタートアップやグレードチェンジにおいて， いかに早く運転が安定するかがよくお分かりいただけることと思う。

ヨーロッパではすでに 100 台以上，北米，カナダでも 7 台, BTFヘッドボックスの新作を含めた受 注あるいは改造の受注が続いている。

何故これほどBTF システムが钦迎されるのか, そのキーポイントを本文で紹介できればと願ってい る。

(本文 68 ベージ)

\section{米国製紙産業における重要な環境問題}

\section{NCASI レイド マイナー}

昨年の秋に製就産業の二酸化炭素排出量の算定法についての意見交换と日本の製紙産業の温暖化への 取組み状況把握のため NCASI の副社長である Reid Miner 氏が来日した。この報告は, 平成 14 年 11 月 20 日に銀座大和ビルで行われた紙バルブ技術協会主催の講演会の内容をもとに演者によってまとめ られたものである。

NCASI とは北米の製林・木材産業が基金を提供して運営している非営利の㻴境研究機関である。1943 年に設立され, ノースカロライナの本部を中心に全米 5 力所に研究施設を有し, 2002 年にはカナタに支 部を開設している。1970年代から製纸工場排水の㻓境への影霜について広範囲な調查研究を実施して

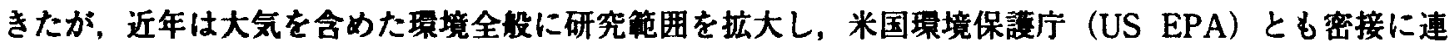
据した研究活動をおこなっている。

(本文 74 ベージ)

\section{製紙工場のクローズド化が機械パルプファイン物性に及ぼす影解}

\section{日本製紙㧣式会社 技術研究所 上條 康幸、宮西 孝則}

TMP 白水中に含まれている溶存コロイド成分（DCS）が, TMP手抄きシートの強度及びファイン 凝集性に与える影震に関して検討を行った。

白水により希釈，籍い分けを行った白水 TMPファイン，水による希釈洗浄，篩い分けを行った洗浄 TMP ファインを調慗し，それぞれをTMP 長樴維に配合して手抄きシートを作成した。作成した手抄 きシートについて，裂断長と IGT 印刷試験による表面強度の評価を行ったところ，ファイン配合量が 增加するに従い織䑾間耛合が強化され裂断長, 表面強度が增加する結果が得られた。配合したファイン を比較したところ，白水 TMP ファインを配合したシート強度は洗浄 TMP ファインを配合した場合よ りも低く，ファインの結合能が低下することが明らかとなった。白水 TMP ファインは白水中に含まれ ているDCSがファイン表面上に吸着されており，瀻維間結合が阻害されたことが結合能に影響を及ほ していたと考えられる。

また，カチオン性歩留向上郕添加による新闕マシン白水中のファイン凝集性に関しても評価を行った。 白水により穊い分けを行った白水ファイン, 白水ファインをアセトンで抽出した抽出ファインの凝集性 を光度分散分析器（PDA）を用いて比較したところ，抽出ファインの凝集性が高い結果が得られた。 この結果もファイン表面上の DCS が除去されたためであると推定される。また，凝集性は歩留向上剂 


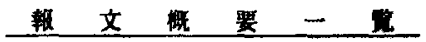

の分子量に依存しており，分子量が大きいほど疑集性が高いことが明らかとなった。

抄紙工程での白水はパルブ化工程での希釈水等として用いられる。本研究で得られた知見は, ワンパ スリテンションの向上や溶存コロイド成分の処理がより重要な課題であることを示唆している。

(本文 83 ページ)

\section{磁性パルプ紙の製造（第 2 報） \\ 一In situ 合成反応法によるフェライト内腔充填パルプの調製一}

\section{爱媛県紙産業研究センター 藤原 勝霜}

in situ 合成反応法によりフェライトをバルブ内些に充填した磁性バルプを調彆した。

二価金属イオンを含む第一鉄堭水溶液にパルブを共存させアルカリを添加し，100 以下で空気酸化 することにより，マンガンフェライト，垔鉛フェライト及びマンガン亜鉊フェライトの in situ 合成反応 条件を見出した。この反応条件を応用して，フェライトをパルブ内脏に in situ 合成する新たな方法を明 らかにした。

マンガンフェライトが生成する領城は, アルカリ添加量が 1.0 当量付近で反応温度は $50^{\circ} \mathrm{C}$ 以上の領 域でマンガンフェライトが生成し，1.5 当量では $60^{\circ} \mathrm{C}$ 以上で, 2.0 当量以上では $80^{\circ} \mathrm{C}$ 以上でマンガン フェライトが生成した。亜鉛フェライト及びマンガン亜鉛フェライトが生成する領域は, アルカリ添加 量が 1.0 1.1 当量付近で反応温度は 50 C 以上の狭い領域でフェライトが生成した。

フェライトのバルブ内臆充填量は，フェライト充填バルブをベースにして，マンガンフェライトで

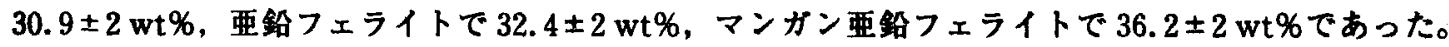

第 1 報のマグネタイト内臆充填量に比較して，ほほ同量ないしは若干多い充填量であった。

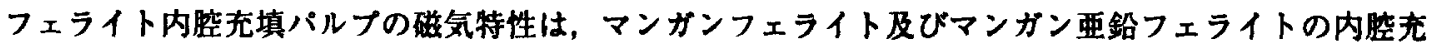
填量が各々 $30.9 \mathrm{wt} \%, 36.2 \mathrm{wt} \%$ の場合の飽和磁化は各々 $15.8 \mathrm{emu} / \mathrm{g}, 21.4 \mathrm{emu} / \mathrm{g}$ of ferrite loaded pulp, 残留磁化は各々 $3.2 \mathrm{emu} / \mathrm{g}, 4.7 \mathrm{emu} / \mathrm{g}$ of ferrite loaded pulp, 保磁力は各々 $107 \mathrm{Oe}, 119 \mathrm{Oe}$ で あった。

(本文 90 ページ) 